This item was submitted to Loughborough's Research Repository by the author.

Items in Figshare are protected by copyright, with all rights reserved, unless otherwise indicated.

\title{
Should charity begin at home? An empirical investigation of consumers' responses to companies' varying geographic allocations of donation budgets
}

\section{PLEASE CITE THE PUBLISHED VERSION}

http://dx.doi.org/10.1007/s10551-015-2832-9

\section{PUBLISHER}

(C) Springer Science+Business Media

\section{VERSION}

AM (Accepted Manuscript)

\section{PUBLISHER STATEMENT}

This work is made available according to the conditions of the Creative Commons Attribution-NonCommercialNoDerivatives 4.0 International (CC BY-NC-ND 4.0) licence. Full details of this licence are available at: https://creativecommons.org/licenses/by-nc-nd/4.0/

\section{LICENCE}

CC BY-NC-ND 4.0

\section{REPOSITORY RECORD}

Schons, Laura M, John Cadogan, and Roumpini Tsakona. 2015. "Should Charity Begin at Home? an Empirical Investigation of Consumers' Responses to Companies' Varying Geographic Allocations of Donation Budgets". Loughborough University. https://hdl.handle.net/2134/20147. 


\title{
SHOULD CHARITY BEGIN AT HOME? AN EMPIRICAL INVESTIGATION OF CONSUMERS’ RESPONSES TO COMPANIES’ VARYING GEOGRAPHIC
} ALLOCATIONS OF DONATION BUDGETS

\author{
Laura Marie Schons \\ Assistant Professor of Marketing \\ Ruhr-University of Bochum \\ Bochum, Germany \\ E-Mail: laura.schons@rub.de \\ John Cadogan \\ Professor of Marketing \\ Loughborough University \\ Loughborough, UK \\ E-Mail: J.W.Cadogan@lboro.ac.uk \\ Roumpini Tsakona \\ PhD student in Marketing \\ Loughborough University \\ Loughborough, UK \\ Email: R.Tsakona@lboro.ac.uk
}

Keywords: Corporate social responsibility; corporate philanthropy; allocation of corporate donations; in-group bias; priority for compatriots; moral intuitions; justice restoration potential. 


\section{SHOULD CHARITY BEGIN AT HOME? AN EMPIRICAL INVESTIGATION OF}

\section{CONSUMERS’ RESPONSES TO COMPANIES’ VARYING GEOGRAPHIC}

\section{ALLOCATIONS OF DONATION BUDGETS}

In our globalized and interconnected world, companies are increasingly donating substantial amounts to good causes around the globe. Many companies choose to donate "at home" while others give to causes in far-away places where recipients are in dire need of support. Interestingly, past research on corporate donations has neglected the question of whether consumers differentially reward companies for geographically varying allocations of donation budgets. Through a mixed-methods approach, this paper remedies this gap by developing and empirically testing a conceptual framework of consumers' preferences for geographically varying allocations of corporate donation budgets. In a first step, two preliminary field studies $\left(\mathrm{N}_{1}=76 ; \mathrm{N}_{2}=80\right)$ involving real donations explored customers' preferences for donation allocations varying in geographical focus. A qualitative focus-group study then investigated underlying rationales to inform the research and led to the development of hypotheses. Subsequently a large-scale between-subjects scenario experiment $(\mathrm{N}=5,770)$ tested the predictions. Overall, results indicate that, in contrast with current managerial practice, customers prefer companies that split donations equally between domestic and foreign recipients or even donate only abroad.

Topic: Marketing and Consumer Behavior

Keywords: Corporate social responsibility; corporate philanthropy; allocation of corporate donations; in-group bias; priority for compatriots; moral intuitions; justice restoration potential. 
"Most rich countries are rich because they are fortunate with resources. America made its wealth through oil, Australia through its gold and coal, etc. It's like being born into a rich family vs being born into a poor family. The rich kids must help the poor kids to make the place a better place to live."

"The idea that we owe them something because our society has been more successful is ridiculous. The only thing we owe them is a blueprint for them to raise themselves out of poverty and despair."

(Quotes from debate.org on the question "Should developed countries help poor, third world nations without expecting debt repayment?" ${ }^{\text {) }}$

In our globalized and interconnected world, companies are increasingly donating substantial amounts to good causes around the globe. According to the Reputation Institute ${ }^{2}$, Microsoft spent \$904 million, Walt Disney \$248.5 million, and Sony \$54.5 million on corporate social responsibility (CSR) initiatives in 2012 alone, underlining the growing importance that support for social issues holds in a company’s strategic and financial planning.

The specific focus of firms’ philanthropic CSR activities, however, varies geographically, with highly heterogeneous allocations of the donation budgets across companies that operate within the same countries. For instance, among US companies, Walmart invests its donations into causes only within the US (“fighting hunger project”) ${ }^{3}$, General Electric spreads its investments world-wide, including within the US ${ }^{4}$, and Exxon Mobile’s donation activities are limited to causes in the third world only ("Exxon Worldwide giving report" ${ }^{\text {5 }}$ ). Academic analyses of such corporate donations have revealed that companies are most likely to donate to

\footnotetext{
${ }^{1}$ http://www.debate.org/opinions/should-developed-countries-help-poor-third-world-nations-without-expectingdebt-repayment.

${ }^{2}$ http://www.reputationinstitute.com/

3 Walmart Global Responsibility Report 2014, p. 65, Walmart Annual Report, p. 36.

4 http://www.gesustainability.com/where-we-work/united-states/.

5 http://corporate.exxonmobil.com/en/community/worldwide-giving/exxonmobil-foundation/overview.
} 
causes in their home regions and in parts of the world where they are operating (Galaskiewicz 1997; Marquis, Glynn, and Davis 2007; Muller and Whiteman 2009).

Interestingly, although numerous studies have examined consumers’ reactions to CSR (e.g., Creyer and Ross 1996; Klein and Dawar 2004; Lichtenstein et al. 2004; Luo and Bhattacharya 2006; Du et al. 2007; Vlachos et al. 2009), research on corporate donations has neglected the question of whether customers differentially reward companies for geographically varying the allocations of their donation budgets. Also, research in related fields, such as that on consumer reactions to cause-related marketing (CRM) activities with varying geographical scopes, offers no conclusive evidence: past research in this area has generated mixed results, with some contributions pointing to consumers’ preference for a local scope of causes (Ross et al. 1990; Grau and Folse 2007; Hou et al. 2008; Vanhamme et al. 2012), some finding insignificant results (Ross et al. 1992), and some even pointing to consumers' preference for a national over a regional scope (Cui et al. 2003).

This investigation addresses the outlined research gap by developing and empirically testing a conceptual framework of customer reactions to varying geographic allocations of corporate donation budgets. In this effort, we rely on a mixed methods approach encompassing four studies. In the first study, we conduct a preliminary field study involving real donations to explore customers’ preferences for geographically varying allocations of donations $(\mathrm{N}=76)$. Results indicate that when faced with the decision to donate either completely at home, completely abroad, or divided equally between home and abroad, most participants prefer the split option because they perceive the 50-50 division to be fair. The second study, which involves an online survey with real donations in which participants can freely pick the allocation 
of the donation between a domestic and a foreign cause on a sliding scale, generates additional support for participants’ preference for a “fair” 50-50 split of donations ( $\mathrm{N}=80)$.

To identify underlying rationales and to inform our research, the third study uses a qualitative approach relying on focus groups, explores the psychological processes underlying customers' responses to companies’ varying donation allocations, and derives formal hypotheses. The results indicate that consumers differ in their perceptions of (1) the morality of favoring their own in-group and (2) the justice restoration potential of corporate donation behavior, and that both considerations may affect their willingness to patronize companies that donate either at home, abroad, or divided between domestic and foreign recipients.

To dig deeper into these potential relationships and to provide generalizable findings, in Study 4 we conducted a scenario experiment among 5,770 non-student respondents of a large German consumer panel to test our predictions. We implement a between-subjects design using scenarios with varying donation allocations by a hypothetical tea company (the "Hildegard Tea Company”). To capture individual differences in reaction to these manipulations, on the basis of quotes from the interviews we develop and integrate a scale capturing customers' perceived morality of favoring the own in-group. Additionally, we measure customers' perceptions of the justice restoration potential of companies’ donation activities (White et al. 2012). Figure 1 provides an overview of the four studies.

Insert Figure 1 about here-

By exploring the differential effects of regional allocations of CSR donations using a mixed methods approach we make four important contributions. First, we provide insights into the differential effects that geographical budget allocations for philanthropic CSR initiatives have on 
customer responses. These insights reveal the moderating role of the perceived morality of favoring the in-group and uncover beliefs regarding the potential of justice restoration in the context of geographically varying donation allocations of companies. Second, we generate empirical evidence on the much-discussed human intuition that "charity should begin at home." Third, we significantly broaden the knowledge on corporate philanthropy by revealing that current managerial practice in allocating donations (often focusing on local causes) is in conflict with customers' preferences. Fourth, on the managerial front, our results relating to the effects of geographically varying donation allocations on consumers’ purchase intentions provide decisionmakers with a powerful tool for developing successful CSR strategies.

Next, we report the preliminary field studies that test whether a preference for varying geographical allocations of donations can be observed on the level of customers' real donation behavior. We then present the qualitative study that serves as a basis for developing our research hypotheses, and follow with a discussion of the research methodology of the field experiment, a presentation of the results, and a brief discussion of the findings. We close by reflecting more generally on the study, identifying managerial implications, and suggesting directions for further research.

\section{Study 1: Field Study on Donation Allocations}

As a first step, we were interested in exploring customers' preferences for allocations of donation budgets differing in geographical focus when the customers themselves are the ones donating. The philosophy literature has intensively discussed the moral intuition that "compatriots take priority,” the political analog of the common belief that "charity begins at home” (Shue 1980). If this assumption about moral intuitions is true, customers should clearly prefer donations favoring the own in-group. To the best of our knowledge, previous research has not empirically 
investigated the rationales for patriotism, nor has it explored customers' perceptions of the morality of companies’ geographically varying donation strategies, which may favor either the own in-group or foreign recipients to which companies have no special relationships but that may be in more need of support. ${ }^{6}$ The studies reported in this paper are devoted to gaining a better understanding of people’s perception of corporate donation allocation decisions and the role of an in-group bias.

\section{Procedure}

To learn more about consumers’ preferences for varying geographical allocations of donation budgets in general, we conducted a field study involving real donation decisions on a German university campus. A sales booth was set up in front of one of the main university buildings. Two student assistants sold mixed bags of a large assortment of sweets using a pay-what-youwant pricing mechanism under which customers could decide what price they would like to pay (Kim et al. 2009; Schons et al. 2013). Passerby customers were informed that they could choose ten items that would be put together in a mixed bag of sweets and that the complete amount they chose to pay would be donated to good causes. They were further asked to choose the cause they wanted the money to be donated to (Robinson et al. 2012): either (1) a local organization supporting the education of children from poor families, which is located close to the university, (2) a distant organization located in Indonesia dedicated to supporting the education of children from poor families in Indonesia, or (3) both causes in equal shares (50\%-50\%). Respondents received information on both causes in the form of printed brochures provided by the charity organizations. We chose to use a cause located in Indonesia because Indonesia is often the focus

\footnotetext{
${ }^{6}$ One similar study by Russell and Russel (2010) explores consumer perceptions of firms' CSR activities with a varying geographical focus in the domain of environmental activities.
} 
of corporate donation activity (and thus is representative of corporate donation activity in faraway regions). Preliminary brainstorming revealed that because many products bought in Germany are produced in Indonesia and customers often envisage these products as being made under sweatshop conditions, probably involving child labor, the thought of the country Indonesia is often linked to feelings of compassion and knowledge of world poverty. Indeed, according to World Bank reports, the per capita GDP in Indonesia in 2007 was only $4.18 \%$ of that of the US. However, in contrast to a country like China, which also exports huge amounts of products to Germany, Indonesia is not thought of as being a fast-growing market economy with increasing wealth for its citizens. Thus, we decided that using a cause in Indonesia for our studies would be an adequate choice.

Participants were asked to fill in a short questionnaire that included an open question asking for their reasons for their donation decision, their perception of the two causes, and their demographics. After the study had been completed, the respective proportions of the donations were donated to the two causes. The cause in Germany was "Förderturm e.V." in Essen and the cause in Indonesia was "Education for Indonesia e.V.”

\section{Results}

During the experiment, 76 mixed sweets bags were sold (42 on day one and 34 on day two). Of the participants, 59.2\% were female and the mean age was 28.57 years. Of the 76 donations, 17.1\% were made to the local cause, $27.6 \%$ were made to the cause in Indonesia, and 55.3\% were split between the two causes. Many customers reported underlying reasons for their decisions. Participants who chose to donate to the local cause typically stated that they liked the fact that by donating they are able to help people from their direct surrounding and that they felt 
a closer relationship to the recipients of the money donated to the local cause. In contrast, respondents who chose to donate to the cause in Indonesia stated that the reason for their behavior was that they felt that the children in Indonesia are more in need of support and that thus the respondents owe them in terms of justice restoration. Finally, the majority of respondents, who decided to split the money between the two causes, explained their decision by stating that the driving force behind the choice to donate to both causes was a consideration of fairness. Many of them stated that charity should begin at home but shouldn't end there, and that they perceived a division of 50\%-50\% of the donation to be the fairest choice.

\section{Study 2: Online Experiment on Donation Allocations}

To explore whether the preference for the 50-50 split was an artefact of the limited choices provided by the experimental design, we conducted a follow-up online survey, again involving real donation decisions in which participants were asked to allocate a donation amount between a domestic and a foreign cause. However, in this new study, participants could pick the allocation of the donation from 11 choices on a sliding scale ranging from $100 \%$ for the domestic cause to $100 \%$ for the foreign cause in $10 \%$ steps.

Further, we chose to investigate in more depth which motives explain customers' decision to donate at home or abroad, or to choose a certain split. For this purpose, we consulted the philosophy literature on the moral intuition that "compatriots take priority" and searched for texts that mention potential rationales for this intuition. Dagger (1985) indeed mentions three psychological rationales that could cause the "priority for compatriots" intuition of which, however, he regards only one to be partly morally convincing. The first is the argument from efficiency, which poses that it is more important to aid the needy among our fellow citizens 
before we look to the needs of foreigners simply because this is the most efficient way to helpwe can satisfy more needs at less cost. He instantly rejects the argument by referring to the extent and severity of the needs. As an example, when balancing the good we can do against the cost incurred by the activity, a starving child in a faraway country would always take priority when compared to a fellow countryman in need of a hearing aid.

The second argument is the argument from side effects. The core of this argument is that helping compatriots could not only help to satisfy the need itself but could also promote solidarity, fraternity, and a sense of community as positive side effects. However, he argues that someone who takes a cosmopolitan view might just as well maintain that a policy that disregards nationality and citizenship will promote feelings of universal community and thereby combat racism. The third argument is the argument from reciprocity, which holds that we should grant priority to our compatriots because, ceteris paribus, we owe it to them owing to a special relationship we share as citizens of the same country. Dagger grants this argument at least limited validity. However, he presumes that all three arguments are possible intuitions that lead to the belief that "compatriots should take priority.” To gain a deeper understanding for respondents' decisions, we chose to measure these three rationales and explore their relevance.

\section{Procedure}

To collect data, we mailed an online survey to students enrolled in a BA course in management. The participants were informed that for each completed questionnaire, a donation of $1 €$ would be made to a good cause. Eighty students responded (62.5\% female; mean age 22.97 years). Within the survey, participants were asked to partition the donation amount between two causes, one domestic and one foreign. The causes chosen for the study were the same as in Study 1, 
“Förderturm e.V.” as a German cause and “Education for Indonesia e.V.” as a foreign cause located in Indonesia.

After having made the allocation decision, participants were provided with the opportunity to express their thoughts and underlying rationales in an open text box. They were then asked to evaluate a set of items capturing the rationales for in-group favoritism named by Dagger (1985) (i.e., efficiency, side effects, reciprocity), as well as controls capturing the perceived importance of the cause and the perceived distance between their home and Essen/Indonesia, because these were rationales named by the participants in Study 1 (represented in statements like "I feel a stronger connection because Essen is close to my home” versus “The kids in Indonesia seem to need the money a lot more than the German kids”).

\section{Measurement}

To capture the perceived efficiency of donations to German/Indonesian causes, four items were used for each cause and summed to create an efficiency score ("Regarding Förderturm/Education for Indonesia, I am sure that the donation reaches the recipients”; “The help that Förderturm/Education for Indonesia provides for the kids in Essen/ Indonesia is effective”; "Förderturm/Education for Indonesia can make a significant change with their work”; “The help that Förderturm/Education for Indonesia provides for the kids in Essen/ Indonesia is efficient”; $\alpha_{\text {Förderturm }}=.918, \alpha_{\text {Education for Indonesia }}=.928$ ). Respondents indicated their (dis)agreement with the statements on a 7-point Likert scale ranging from "I do not agree at all” to "I fully agree.”

For the measurement of potential positive side effects of donations to German/Indonesian causes, three items were used for each cause and summed to form two equally weighed scores (“Supporting a cause like Förderturm/Education for Indonesia strengthens the solidarity amongst 
Germans/humans"; "Social projects in Germany/International social projects strengthen the feeling of we-ness in Germany/in the world"; "Projects like Förderturm/Education for Indonesia help to foster trust in the German society/the world society"; $\alpha_{\text {Förderturm }}=.921 ; \alpha_{\text {Education for }}$ Indonesia $=.925$ ). Participants indicated their agreement with the statement on a 7-point Likert scale ranging from "I do not agree at all” to "I fully agree."

To capture the rationale of reciprocity, three items were included for each of the causes and integrated to form two equally weighed measures ("A project like Förderturm/Education for Indonesia should be supported because we owe it to the kids in Essen/Indonesia"; "I feel connected to the kids in Essen/Indonesia and feel that I am responsible for helping them"; "We should give back to the German community/to the international community"; $\alpha_{\text {Förderturm }}=.863$; $\left.\alpha_{\text {Education for Indonesia }}=.898\right)$.

For the perceived need and importance of the two causes, three items were used for each cause and integrated to form two equally weighted measures ("The need of the kids in Essen/Indonesia is high”; "Förderturm/Education for Indonesia is a very important project”; "The kids in Essen/Indonesia are in dire need of support"; $\alpha_{\text {Förderturm }}=.905 ; \alpha_{\text {Education for }}$ Indonesia $=.932)$.

Finally, to capture the intuitive feeling that Essen/Indonesia is near or far away, we integrated two semantic differential items: “(a) Essen / (b) Indonesia is close (1) ... far-away (7)”

\section{Results}

The results provide additional strong support for the assumption that people have a preference for 50-50 splits of donation amounts between domestic and foreign recipients because they feel that this is the fairest allocation. Out of the 80 respondents, 36 (45\%) chose the 50-50 split 
between Förderturm and Education for Indonesia. Twelve respondents (15\%) chose to donate 100\% to Förderturm and 13 (16.25\%) allocated 100\% of the donation to Education for Indonesia. This frequency distribution is very similar to the results found in Study 1 and thus generates strong support for the results. Nineteen respondents (23.75\%) chose other splits. Figure 2 provides a detailed overview of the frequencies of allocation decisions and sample statements that respondents gave as rationales for their decisions:

-Insert Figure 2 about here

A regression analysis using the percentage of the donation allocated to the foreign cause (Education for Indonesia) as a dependent variable and effectiveness, side effects, reciprocity, perceived need and importance, and perceived distance as independent variables provides further insight into the reasons for the decisions. Only the perceived need and importance of the cause and the perceived obligation to reciprocate to the international community significantly predict the allocation decision $\left(\beta_{\text {need\&importance Förderturm }}=-.478, p<.001 ; \beta_{\text {need\&importance Education for Indonesia }}=\right.$ $\left..298, p<.060 ; \beta_{\text {reciprocity international }}=.379, p<.021\right)$.

\section{Discussion of Study 2}

Both preliminary field studies indicate that, on average, customers have an inherent preference for splitting donation budgets between domestic and foreign recipients. The reported rationale for this decision is that 50-50 splits are perceived as the fairest option. Interestingly, this rationale contradicts the assumption often put forward by philosophers (e.g., Shue 1980; Dagger 1985; Goodin 1988) that people have an inherent preference to allocate resources in favor of their own in-group of compatriots. In contrast, many people even prefer allocations in favor of foreign recipients to remedy global injustices. Results indicate that the perceived need and 
importance of the cause is a significant predictor of allocation decisions. Supporting Dagger’s proposition (1985) that arguments of reciprocity influence people’s resource allocation decisions, we find that the feeling that one should give back to the international community is a significant determinant of donations favoring foreign recipients. In contrast with the results found in this study, Dagger proposed that the feeling of reciprocity should manifest in a stronger in-group bias. However, the respondents in this study seem to apply a far more universalistic morality than has been proposed by previous non-empirical contributions to this field.

Still, the donation allocations exhibit significant variance. In Study 3, focus-group interviews were used to explore customers' perceptions of corporate donation allocations and to derive formal hypotheses that were subsequently tested in the field experiment.

\section{Study 3: Focus-Group Interviews}

The main goal of the two preliminary studies was to gain an understanding of respondents’ general preference for donation allocations. The focus group interviews were conducted to inform our conceptualization of consumer perceptions of companies' varying geographic allocations of their donation budgets. Combined with existing theory, the results of the qualitative research have been used for scale development and to derive formal research hypotheses.

\section{Method}

\section{Design}

We conducted three focus groups (4-6 participants each) with consumers differing in terms of age and occupational status. No financial incentives were offered for taking part in the qualitative study, and the specific goal of the research was not communicated to the participants. 
After completion of the interviews, participants were thanked for their contribution and were informed about the purpose of the study in a debriefing.

\section{Procedure}

The focus groups were conducted by a research assistant well trained in qualitative research who was familiar with the subject. To start off with more general questions and to ensure an equal understanding, the moderator opened the interviews with the question of whether the consumers had an idea of what the term corporate social responsibility means and what facets it encompasses. Participants were then asked how corporate donation budgets should be distributed geographically and whether the nature of the company would make a difference to them (in terms of whether the company is a domestic firm or operating on a global scale). All interviews were video- and audio-recorded and transcribed. The data analysis was based on qualitative content analysis, and QSR NVIVO, a software package for qualitative data analysis, was used to code, manage, and explore the transcripts. The analysis followed an iterative approach, traveling back and forth between the data and the emerging theory (Eisenhardt 1989). We refrain from reporting quantitative counts of quotes from the interviews. However, if not specified further, the quotes reported in the results section represent the majority opinion in all three focus groups.

Results of the Focus Group Discussions and Derivation of Research Hypotheses

\section{Customers' Perceptions of Geographically Varying Allocations of Donation Budgets}

In a first step, the interviewer asked very generally (without referring to specific CSR activities or domains) whether donation budgets of firms should be spent in the home country, in foreign countries, or divided between domestic and foreign recipients. Supporting the findings of the two preliminary field studies, across all three focus groups participants expressed a clear consensus 
that CSR budgets should somehow be “fairly distributed” between the own country and recipients in other countries (Respondents B,D,E: “It should be fairly allocated”). As respondent K put it, "When some donations are invested in the rainforest, others used to fight hunger in Africa, and again others used to support local sport clubs in Germany, everybody gets their piece of the cake”. In line with the preliminary studies, the rationale that respondents gave for their position was that this split appeared to be the fairest solution to them. In their eyes, although donations were raised through domestic consumption, the poorer regions of the world should also benefit from the wealth of Western societies. Thus corporate donations could help to remedy global injustices.

The statements of the respondents are also consistent with recent research results from psychology (e.g., Takagishi et al. 2010) and experimental economics (e.g., Fehr and Schmidt 1999) that consistently confirm that people have an inherent preference for fair allocations. This preference for fairness leads them to favor shared allocations of resources (in experimental games like the Ultimatum Game, 50-50 shares are the most frequent observation) and to disapprove of biased splits.

The discussions in the focus groups further revealed that this preference for fair splits can lead to a preference (in terms of purchase intentions) for companies that split their donations between domestic and foreign recipients. For instance, respondent O remarked, "If I would be faced with the decision to choose between the products of two companies of which one donates only at home and the other also takes care of people in the third world, I would definitely choose the latter." 
On the basis of the results of the preliminary field study, the quotes from the focus group interviews, and the related theoretical background, we thus propose that customers will have a preference for companies that donate at home and abroad in equal shares:

H1 Customers' purchase intentions will be higher for companies that equally split their donations between domestic and foreign recipients than for companies that donate only at home or abroad.

\section{Perceived Morality of Favoring the Own In-group}

Besides this basic prediction, the quotes from the interviews reveal that customers vary in their perceived morality of allocations that favor the own in-group. On the one hand, it was of special importance to some of the respondents that foreign CSR activities be preceded by domestic investments. As respondent K notes, "It might sound egoistic, but even here at home we have deficits that could be targeted and those are important to me as well, not only poor children in other countries.” In line with this, respondent L adds, “I have a quite similar opinion. Companies should first of all care for a solid basis at home before donating to third world countries.” Or, as respondent I puts it, "First of all, everybody should put his own house in order first.” Thus, for these respondents a firm's allocation of donation budgets that favors the own in-group would not necessarily be immoral. They might even think that, from a moral perspective, charity should begin at home. This response is in line with the prediction of philosophical contributions that people have an inherent preference for resource allocations that favor the own in-group (Shue 1980; Goodin 1988; Dagger 1985).

On the other hand, another group of respondents insisted that a company’s allocations of CSR budgets that favors the own in-group (donating predominantly in Germany) is immoral (respondent $\mathrm{O}$ claims that "in my opinion, the poorest should be taken care of first! Children who 
have nothing, no medical care, who really need it!”). In the eyes of these respondents the main allocation criterion should be the neediness of the recipients, and as in the poorer regions of the third world many recipients are in dire need, companies should mainly spend their donation budgets there. Hence, for these respondents a company's allocation of donation budgets that focuses on recipients at home (i.e., favoring the own in-group) would clearly be immoral. This finding contradicts the assumption of something like a moral intuition of in-group favoritism per se. Indeed, as the preliminary studies indicated, such intuitions seem to be much more complex and multi-facetted than simply assuming that "compatriots take priority."

In a next step, the interviewer asked the groups whether this attitude regarding the moral rightness of donating charitable budgets locally or in foreign markets would lead them to consciously choose products from companies who donate either at home or abroad. Indeed, respondents who believe that a company's more domestic allocation of donation budgets is perfectly moral explained that they would have a higher purchase intention if a given company primarily supports causes at home. In turn, respondents who proclaimed that they believe a company's allocation of donation budgets favoring the own in-group to be immoral reported that they prefer companies that donate to causes in the needy foreign countries.

Given this considerable variance in attitudes, we hypothesize that the individually perceived morality of companies’ allocations of donations budgets that favor the own in-group will have a moderating effect on customers’ reactions to companies’ allocation decision for donation budgets. More specifically, we assert that those customers who believe that companies should care for their own people first will react more positively (in terms of purchase intentions) to firms allocating donation budgets in the domestic market and be less responsive to companies sharing the cake with foreign recipients. On the other hand, those who believe that companies 
have a moral imperative to donate to needy foreign causes as a priority will show higher purchase intentions when receiving information indicating that the firm behaves this way. Accordingly:

H2 Customers' perceived morality of companies' allocations of donations budgets favoring the own in-group will have a moderating effect on their purchase intentions for companies with varying geographic allocations of donation budgets.

H2a Customers who perceive that it is moral for companies to allocate donation budgets to favor the own in-group will show a higher purchase intention for companies that only donate at home relative to customers who perceive that it is immoral for companies to allocate donation budgets to favor the own in-group.

H2b Customers who perceive that it is moral for companies to allocate donation budgets to favor the own in-group will show a lower purchase intention for companies that only donate abroad relative to customers who perceive that it is immoral for companies to allocate donation budgets to favor the own in-group.

\section{Justice Restoration Potential}

In line with the literature on whether corporate actors have the potential to restore global justice (White et al. 2012), discussions encompassed this aspect in all three focus groups, and in all groups, the subject of a justice restoration potential emerged naturally from the participants' own comments (i.e., before the interviewer could raise justice restoration potential issues). The respondents discussed whether MNCs really have the potential to change the predicaments of the inhabitants of the poorer parts of the world. Most respondents were rather optimistic about the question, seeing the possibilities instead of the drawbacks of global philanthropic engagement of big companies. As respondent K summarizes, “Of course they cannot save everybody or change everything at once, but I believe that companies can make a step-by-step change.” However, a smaller group of respondents also uttered their skepticism of whether companies' donations in the third world can really make a change in terms of justice restoration or merely boost sales volumes by enhancing consumer attitudes toward the company. Thus, whereas most respondents 
tended to believe in firms' abilities to contribute to a more just world, their views nevertheless still seem to vary considerably.

The interviewer raised the issue of whether respondents’ beliefs about companies’ justice restoration potentials would lead the respondents to actively seek out products that are produced by companies donating to third world countries. Whereas those respondents who did not believe that corporate donations can make a change toward more justice in the world stated that they did not very much care about a company’s engagement in poor countries, those who said they believed in a justice restoration potential reported that they had frequently bought products that are linked to donations to poorer countries. This result directly ties in with the results of White et al. (2012), who find that customers who believe in a justice restoration potential of corporate actions are more likely to purchase fair trade products.

On the basis of research on customers' belief in a justice restoration potential of companies offering ethical products and drawing on the quotes from the focus group discussion, we anticipate that customers’ beliefs regarding companies’ abilities to make changes and reduce global inequalities by donating to good causes in poor countries will play a moderating role in determining consumer reactions to varying allocations of corporate donation budgets:

H3 Customers' beliefs regarding the justice restoration potential of corporate donations will have a moderating effect on their purchase intentions for companies with varying geographic allocations of donation budgets.

H3a Customers who have a strong belief in the justice restoration potential of corporate donations will show a lower purchase intention for companies that only donate at home as compared to customers who have a weak belief.

H3b Customers who have a strong belief in the justice restoration potential of corporate donations will show a higher purchase intention for companies that only donate abroad as compared to customers who have a weak belief. 
Complementing these formal hypotheses, the focus group discussions gave rise to two further research propositions, which for the sake of conciseness will not be formally derived but will be considered in the upcoming empirical study. These hypotheses are summarized in the following.

\section{Small versus Large Budgets}

In general, respondents agreed that companies should allot substantial amounts of their profits to social causes. All three focus groups expressed a consensus that after costs have been covered, companies should invest the majority of their profits in good deeds. This finding in itself is novel and interesting and might be symptomatic of a shift in how people view the roles and responsibilities of private businesses. Respondent A even specified, "If there are profits, they [the companies] should spend about $90 \%$ of these profits for good deeds.” Thus, we expect that larger donation budgets will on average be preferred over smaller ones.

\section{Domestic versus Multinational Companies}

The interviews also revealed that the question of where the budgets should be spent depends in part on the extent of operations of the donating company (i.e., whether it is a domestic firm or a company with global operations). In respondents' eyes, small domestic firms should spend their CSR budgets locally, whereas companies that are operating in multiple countries should engage in global CSR activities. As respondent A remarks, "In my opinion, a much bigger part of the budget should be used locally if the company is a small or medium-sized enterprise. In contrast to this, big players should rather engage in global CSR activities.”

\section{Study 4: Scenario Experiment}


To test our hypotheses and propositions we conducted a scenario study. We examined the effects of geographically varying allocations of companies’ donation activities on subjects’ purchase intentions using a 3 (allocation of the CSR budget) x 2 (company reach) x 2 (size of the CSR budget) between-subjects design. The allocation of the CSR budget had three levels $(1=100 \%$ at home, $2=50 \%$ at home, $50 \%$ abroad, and $3=100 \%$ abroad). The company size factor had two levels ( $1=$ operates only in Germany and 2 = operates all around the world), and finally the size of the CSR budget factor had also two levels ( 1 = small CSR budget of 20,000€, 2 = large CSR budget of $1,000,000 €)$.

To achieve unbiased results and avoid consumers’ preexisting perceptions regarding an established, well known company, we created a fictitious tea company, "The Hildegard Tea Company” (Low and Lamb 2000). To enhance external validity and generalizability of the results, real consumers from a large German consumer panel participated in the study.

\section{Data Collection}

In April 2014, the research team sent an invitational email to 20,000 consumers, providing them with information on the purpose of the study and a link to the study's web survey. A total of 5,770 German consumers completed the questionnaire (response rate $28.85 \%$; $72 \%$ of the respondents are female ${ }^{7}$ ). As an incentive for participation, shopping vouchers were raffled among all respondents who finished the questionnaire (10 vouchers for $20 €$ and one voucher for $100 €)$. Table 1 provides the demographic details of the respondents.

-Insert Table 1 about here

\section{Experimental Treatments}

\footnotetext{
${ }^{7}$ Additional analyses devoted to potential gender-related differences in the effects are provided in the results section.
} 
Participants were randomly assigned to one of 12 conditions. The scenario started by providing respondents with some background information on The Hildegard Tea Company, followed by the manipulations of the company’s extent of operations (i.e., company reach), size of the CSR budget, and geographic allocation of the CSR budget. For general information on the company, respondents read:

The Hildegard Tea Company was founded by the family Rupertsberg in the small village of Bingen in 1878 and has since produced a collection of teas, which are mixed according to the traditional recipes of Hildegard of Bingen. The raw tea ingredients are obtained from Indonesia.

\section{Company's Reach of Operations}

The manipulation of the company's extent of operations has two levels. In the condition where the company only operates only in Germany, the participants learn that "Hildegard Tea is a very popular German tea only available in stores in large German cities.” On the other hand, in the condition in which the Hildegard Tea Company resembles a global firm the text read: "Hildegard Tea is a very popular German tea whose products are available in stores in every large city around the world.”

\section{Size of the CSR Budget}

For the manipulation of the size of CSR budget we also employed two conditions. In the large CSR budget condition, participants read that “during the last year, the company donated $1,000,000 €$ to social causes supporting children in need.” In the small CSR budget condition, respondents learned that "during the last year, the company donated 20,000€ to social causes supporting children in need.”

\section{Allocation of the CSR Budget}


At the very end of the scenarios, respondents received information regarding the allocation of the CSR budget, which is the main manipulation of this study. In the CSR budget allocation " $100 \%$ at home" condition, participants learned that "the entire 20,000€/1,000,000€ have been transferred to a child aid organization in Germany." In the CSR budget allocation “ $50 \%$ at home and 50\% abroad" condition, the respondents read that "half of the 20,000€/1,000,000€ have been transferred to a child aid organization in Germany, the other half to a child aid organization in Indonesia,” while in the budget allocation “100\% abroad” condition participants learned that “The entire 20,000€/1,000,000€ have been transferred to a child aid organization in Indonesia."

\section{Measurement}

\section{Consumers’ Perceived Morality of Allocations Favoring the In-group}

To articulate the concept of perceived morality of allocations of donations favoring the own ingroup as clearly and thoroughly as possible, we comprehensively examined the literature on closely related constructs (e.g., ethnocentrism, consumer ethnocentrism). As a result, we define consumers’ perceived morality of allocation decisions that favor the in-group as the extent to which consumers perceive it to be morally appropriate for a company to favor its own in-group over foreigners in its philanthropic CSR activity. Following traditional scale development procedures (Netemeyer et al. 2003), and building on contemporary developments in applied measurement, we generated a pool of items, with each item designed to capture the construct in its entirety. Resarcher-designed items were supplemented with items inspired by the focus groups with consumers.

Three expert judges (a marketing professor and two $\mathrm{PhD}$ students familiar with the research) assessed the content and construct validity of the items. They evaluated the clarity and 
conciseness of the items and made suggestions for reformulations where necessary, resulting in a set of six potential measurement items. Following Netemeyer et al. (2003), a quantitative pretest was conducted to evaluate the items and to eliminate those not meeting standard psychometric criteria. In total, 52 student participants completed a questionnaire containing the six items. The data were subjected to exploratory factor analysis using principal axis factoring and oblique rotation. Two latent factors were uncovered (68.6\% explained variance), with the first factor explaining $46.6 \%$ of the common variance, whereby the first factor contains the items worded in a positive way and the second factor contains reversed items. To create an easy to understand scale we retained the three items from the first factor for further analysis. The resulting scale exhibits a high internal consistency with a Cronbach’s alpha value of .847, which cannot be increased further by excluding items.

\section{Justice Restoration Potential}

Using a two-item scale from White et al. (2012), we assessed consumers’ perceptions of justice restoration potential (e.g., "I can depend on certain companies to help make the world a fairer place for everyone”). For a full list of all items please refer to the Appendix.

We also decided to control for important alternative explanations of our results, namely customers' perceived importance of cause, attitude toward philanthropy, involvement with the product category tea, and attitude toward the out-group of Indonesians.

\section{Perceived Importance of Cause}

Two semantic differential items based on Lichtenstein et al. (2004) were integrated to capture the perceived importance of the cause (e.g., "Support for children in need is ... a) of low importance to me (1); b) of high importance to me (7)”). 


\section{Attitude toward Corporate Philanthropy}

To capture the extent to which consumers have positive attitudes toward corporate philanthropy, three items based on Lichtenstein et al. (2004) were included (e.g., "I strongly believe that companies should donate some of their profits to children's charities”).

\section{Product Category Involvement}

One item adapted from Cleveland et al. (2009) captured consumers’ product category involvement (i.e., "Tea is very important to me”).

\section{Attitude toward the Out-group}

One item, based on Bizumic et al. (2009), assessed consumers' attitudes toward the out-group (i.e., "I have a very positive attitude towards Indonesian people").

Finally, participants indicated their intentions to purchase the company’s products and provided some socio-demographic characteristics.

\section{Purchase Intention}

Three items adopted from White et al. (2012) (i.e., “I would be likely to purchase this company’s products," "I would likely make this company one of my first choices in this product category," and "I would exert a great deal of effort to purchase this company's products") were used to measure our key dependent variable, consumer's purchase intentions.

\section{Socio-demographic Characteristics}

At the end of the questionnaire, participants indicated their age, gender, income, and education, which also served as controls. 
Table 2 gives an overview of the descriptive statistics and the correlations between the constructs. A full list of all measures and scale evaluations is provided in the Appendix. The measurement items, both multi-item and single-item measures, were entered into a confirmatory factor analysis (CFA) using maximum likelihood estimation in LISREL 8.71 to assess discriminant (between-measures) and convergent (within-measure) validity. To identify the single-item latent variables in the CFA model, we specified the single-item error variances following Jöreskog and Sörbom (1993): an item reliability (r) of .70 is assumed, and the error variance of the indicator is set at $[(1-r) \times S 2]$, where $S$ is the sample standard deviation of the indicator.

Two items were eliminated owing to problems with correlated errors (indicating lack of discriminant validity), and the following fit information was obtained: $\chi^{2}=304.10$, $\mathrm{df}=46$; root mean square error of approximation $($ RMSEA $)=0.031$; non-normed fit index $(\mathrm{NNFI})=0.99$; comparative fit index $(\mathrm{CFI})=1.00$; standardized root mean square residual $(\mathrm{SRMR})=0.01$. Although the chi-square result is significant, the relatively large sample size means that even tiny discrepancies between the model-implied covariance matrix and the matrix obtained from the data are picked up and inflate chi-square (e.g., a sampling distribution that is assumed to be multivariate normal under maximum likelihood estimation but that is not exactly multivariate normal in reality would inflate the chi-square result dramatically under a large sample size). Accordingly, in addition to using chi-square analysis, we examine the approximate fit information carefully: we see that the RMSEA and SRMR are approaching 0, and that the NNFI and CFI are approaching 1, which indicates excellent model fit. We also note that all the composite reliability and average variance extracted (AVE) values exceed proposed rules of thumb (Bagozzi and Yi 1988), and that in support of discriminant validity, the lowest AVE 
exceeds the highest squared correlation between the latent variables (Fornell and Larcker 1981). Accordingly, we use the measures presented in the Appendix to assess the hypotheses (see Table 2 for descriptive information on the latent variables).

-Insert Table 2 about here-

Results

Manipulation Checks

To check whether the manipulations worked as intended, we integrated some items capturing respondents' perception of whether the donation allocation favors the own in-group, their perceived size of the donation budget, and whether they understood that the Hildegard Tea Company is either a domestic or a global company. All items were measured on 7-point Likert scales. Respondents' perception of the company's allocations as favoring the own in-group or foreigners was captured by the following two semantic differential items: "The Hildegard Tea Company ... 1) supports the interest of German people versus 2) supports the interests of foreign people” and “The Hildegard Tea Company... 1) favors Germans versus 2) favors foreigners.” For both items, the manipulation of the geographic allocation of the donation budget has a significant effect (item 1: mean $_{100 \%}$ at home $=3.88 ;$ mean $_{50-50}=2.88 ;$ mean $_{100 \% a b r o a d}=2.64,[F(2$, 726), $p=.000]$; item 2: mean $_{100 \%}$ at home $=3.80$; mean $_{50-50}=3.05 ;$ mean $_{100 \% \text { abroad }}=3.00,[\mathrm{~F}(2,381), p$ $=.000])$.

To check whether respondents understood the manipulation of the size of the CSR budget, we integrated the following semantic differential item: "The Hildegard Tea Company ...1) invests little money in social causes versus 2) invests substantial amounts in social causes.” The manipulation indeed significantly affects the responses to this item, with the mean being 
3.28 in the group where the communicated donation budget amounted to $20,000 €$ and 4.21 in the group where the budget was 1,000,000€ [F(1, 1248), $p>.001]$.

Finally, respondents' perception of the reach of the company’s operations was captured by the following item: “The Hildegard Tea Company ... 1) is a domestic German company versus 2) is a globally operating company.” The means in the experimental groups are 1.84 in the groups where The Hildegard Tea Company was described as available in shops in Germany only and 3.04 in groups where the availability was said to be global [F(1,2095), $p<.01]$.

Thus, on the basis of the results of the manipulation checks, we can assume that all experimental treatments had the intended effects.

\section{Main Effect of Geographic Budget Allocation}

We performed a 3 (allocation of the CSR budget: 100\% at home, 50\% at home/50\% abroad, and 100\% abroad) x 2 (company reach: domestic, global) x 2 (size of the CSR budget: small, large) analysis of variance (ANOVA) on consumers' intentions to purchase the company's products. The results revealed a significant main effect of the geographical allocations of donation budgets on consumers' purchase intentions for the three conditions $[\mathrm{F}(2,5.745)=47.50, p<.01]$. Consistent with Hypothesis H1, consumers reported significantly lower purchase intentions in the groups in which budgets were spent only at home $\left(\mathrm{M}_{\text {only home }}=3.70, \mathrm{SD}=1.59\right)$ than when the budgets were either fairly distributed in terms of a 50-50 split between domestic and foreign investments $\left(\mathrm{M}_{50 / 50}=4.11, \mathrm{SD}=1.57\right)$ or spent only abroad $\left(\mathrm{M}_{\text {only abroad }}=4.04, \mathrm{SD}=1.58\right)$. $\mathrm{A}$ Bonferroni post-hoc test confirmed that the difference between the first two groups is significant.

Taken together, these results provide clear evidence for our assumption that customers prefer to patronize companies that balance their donation budgets and include domestic as well as foreign recipients. This finding supports the results of all previous studies (Study 1, Study 2, 
and Study 3) and thus delivers strong support for our basic assumption. Figure 3 graphically illustrates this main effect.

-Insert Figure 3 about here

Moreover, we find a main effect of budget size indicating that consumers in general prefer large budgets over smaller ones and a main effect of justice restoration potential, indicating that customers who have a strong belief in the justice restoration potential of corporate donations have on average a higher intention to purchase from the Hildegard Tea company, which in all scenarios is presented as a company that engages in charitable giving.

In the following, we analyze the moderating effects of perceived morality of favoring the in-group and of justice restoration potential beliefs. Figure 4 presents a graphic overview of the moderating effects.

\section{Moderating Role of Perceived Morality of Allocations Favoring the In-group}

With respect to consumers’ purchase intentions, we find a significant interaction effect between the geographical allocation of the donation budget and consumers' perceived morality of allocations favoring the in-group [F $(2,5.745)=12.83, p<.01]$. As predicted in Hypothesis H2, results reveal that consumers who believe that it is morally acceptable for a company to prioritize the interests of its own in-group over the interests of foreigners do not reward companies for sharing their donation budgets with foreign recipients: purchase intentions are not significantly different across the three groups $\left(\mathrm{M}_{\text {only home }}=3.90 ; \mathrm{M}_{50 / 50}=3.99 ; \mathrm{M}_{\text {only abroad }}=3.97\right)$. Conversely, consumers who believe that favoring the own in-group is immoral indeed reward companies for sharing their CSR budgets between home and abroad $\left(\mathrm{M}_{\text {only home }}=3.68 ; \mathrm{M}_{50 / 50}=4.18 ; p<.001\right)$ or even investing their entire CSR budget in foreign countries $\left(\mathrm{M}_{\text {only abroad }}=4.01\right)$. A Bonferroni 
post-hoc test reveals that whereas the difference between donating only at home and splitting budgets equally is statistically significant, this is not the case for the difference between a 50-50 split and donating only abroad.

\section{Moderating Role of Justice Restoration Potential}

We further examined whether the geographical allocation of donation budgets affects consumers' purchase intentions contingent on their perceptions of the justice restoration potential of such activities. Results reveal a weakly significant interaction effect between the geographical allocation of donation budgets and consumers' perceptions of justice restoration potential on their purchase intentions $[F(2,5.745)=4.39, p<.10]$. In line with Hypothesis H3, respondents' strong belief in the justice restoration potential of corporate donations is reflected in higher purchase intentions for companies that either split their donation budgets between domestic and foreign recipients $\left(\mathrm{M}_{\text {only home }}=3.93 ; \mathrm{M}_{50 / 50}=4.26 ; p<.001\right)$ or choose to allocate the whole budget to foreign recipients $\left(\mathrm{M}_{\text {only abroad }}=4.22\right)$. Again, according to a Bonferroni post-hoc test, whereas the difference between the first two groups is statistically significant (i.e., only home and 50-50), this is not the case for the latter two (i.e., 50-50 and only abroad). For consumers with a strong belief in justice restoration potential, purchase intentions are not affected by whether the donation amount is split between domestic and foreign recipients or spent only abroad. However, results reveal a different pattern for respondents with a low belief in the justice restoration potential of corporate donations: whereas purchase intentions increase significantly from spending the budget only at home to a 50-50 split $\left(\mathrm{M}_{\text {only home }}=3.65 ; \mathrm{M}_{50 / 50}=3.91 ; p<\right.$ .001), purchase intentions decline significantly when comparing the 50-50 split to spending money only abroad $\left(\mathrm{M}_{50 / 50}=3.91 ; \mathrm{M}_{\text {only abroad }}=3.76 ; p<.001\right)$. 


\section{Additional Analyses}

A significant interaction effect also occurs between the geographical allocation of the donation budget and the size of the donation budget on consumers' purchase intentions $[\mathrm{F}(2,5.745)=$ 4.31, $p<.05]$. The positive main effect of sharing the donation budget with foreign recipients is enforced by an increasing budget size. Whereas for small budgets the increase in purchase intentions is rather small $\left(\mathrm{M}_{\text {only home }}=3.80 ; \mathrm{M}_{50 / 50}=3.98 ; \mathrm{M}_{\text {only abroad }}=3.95\right)$, for large budgets the increase is much larger $\left(\mathrm{M}_{\text {only home }}=3.78 ; \mathrm{M}_{50 / 50}=4.19 ; \mathrm{M}_{\text {only abroad }}=4.03\right)$. A Bonferroni post-hoc test indicates that whereas the increase from only home to $50-50$ is statistically significant in both groups, the difference between 50-50 and only abroad is significant only for the large budget group.

We also find a weakly significant interaction effect between the geographic allocation of the donation budget and the company's reach of operations on the consumer's purchase intentions $[\mathrm{F}(2,5.745)=2.75, p<.10]$. For domestic companies only, consumers' purchase intentions are significantly higher when the company offsets its CSR investments between domestic and foreign causes as compared to when it invests in causes only at home or only abroad $\left(\mathrm{M}_{\text {only home }}=3.77 ; \mathrm{M}_{50 / 50}=4.12 ; \mathrm{M}_{\text {only abroad }}=3.94 ; p<.001\right)$. For MNCs, purchase intentions are higher when the company splits the donation budget between domestic and foreign recipients as compared to when it invests only in causes at home, and purchase intentions do not increase further from 50-50 to only abroad $\left(\mathrm{M}_{\text {only home }}=3.81 ; \mathrm{M}_{50 / 50}=4.04 ; \mathrm{M}_{\text {only abroad }}=4.05\right)$.

Robustness Checks

Non-response Bias 
To check for non-response bias, we compared early respondents to late ones, who answered the questionnaire only after a reminder mail. The two groups are comparable on various sociodemographic measures (age, sex, income, and education), and do not differ significantly on key variables, such as perceived morality of donation allocations favoring the in-group, justice restoration potential, and purchase intention.

\section{Common-method Variance}

Common-method variance (CMV) can be a problem in any single-source survey-based study that uses the same type of scales (e.g., Likert-scales). Therefore, we conducted Harman's single factor test in line with recommendations of Podsakoff et al. (2003). The unrotated factor solution for all variables in the questionnaire revealed 12 factors with Eigenvalues greater than one, accounting for $55.78 \%$ of the total variance (the first factor accounts for $25.34 \%$ of the total variance), strongly suggesting the absence of a single general factor in the data set.

\section{General Discussion}

The results of the first exploratory field experiment indicate that, on average, participants seem to have a preference for "fair" allocations of corporate and private donations between domestic and foreign recipients, represented by equal splits of donation amounts. "Charity should begin at home — but should not end there” thus obviously represents the majority opinion among the respondents. However, the observations show considerable variance, with a significantly large group of participants choosing the option to donate the full amount to domestic recipients and an even larger group deciding to donate completely abroad. The second preliminary study exploring participants' preferences for donation allocations on a sliding scale generated additional support for the results from Study 1. The majority of respondents chose the "fair split" of 50-50. Further, 
this second study provided important insights regarding the determinants of donation allocations whereby the perceived need and importance of the cause serves as a significant predictor of donations favoring foreign recipients. In addition, the feeling that one should give back to the international community also had a significant effect on the share of the donation allocated to foreign recipients. Through its qualitative approach, the third study builds a foundation for a conceptual model of consumer reactions to companies’ varying geographical allocations of budgets for philanthropic CSR actions. The focus group discussions deliver additional support for consumers’ general preference for “fair” (i.e., 50-50) splits of donations, especially in cases where these donations are not made by themselves but by companies. Further, results identify as important contingency factors consumers’ belief in a justice restoration potential of corporate donations as well as their perceived morality of companies' allocations of donations budgets that favor the own in-group. On the basis of the preliminary field studies and the focus-group discussions, we developed formal hypotheses and subsequently tested these in the experimental field study.

In line with the preliminary studies, the field experiment confirms that, on average, balanced allocations of CSR budgets (50\% at home and 50\% abroad) lead to the highest purchase intentions, and customers least prefer companies that do not split donation budgets and favor domestic recipients. Further, in general larger donation budgets lead to higher purchase intentions than smaller budgets. Moreover, our results confirm that, as hypothesized, the individual difference factors of perceived morality of allocations favoring the in-group and consumers’ belief in a justice restoration potential of corporate donations significantly affect the basic relationships. 


\section{Theoretical Implications}

This study is the first to investigate customer reactions to geographically varying allocations of companies’ donation budgets. Through a mixed methods approach, we deliver and integrate qualitative (Study 3) and quantitative (Studies 1, 2, and 4) support for our propositions, involving large representative samples (Study 4), experimental techniques (Studies 1, 2, and 4), and the observation of actual purchase and donation behavior (Studies 1 and 2). Thereby, we make three important contributions to CSR research and CSR management.

First, we contribute to the stream of literature on customer reactions to CSR strategies. By exploring customers' perceptions of geographically varying philanthropic CSR strategies we lay the foundation for knowledge in this area. Although past research has explored how companies decide to allocate their donation budgets (Galaskiewicz 1997; Marquis, Glynn, and Davis 2007; Muller and Whiteman 2009), investigations have supplied no answers to the question of how customers react to such managerial decisions. We develop and test a conceptual model of consumers' evaluations of companies’ donation allocations favoring either the own in-group or taking into account the interests of foreign recipients. Thereby, we integrate two important moderating factors that explain variance in individual responses: through our preliminary studies, focus group interviews, and review of the literature on the moral intuition that "compatriots take priority,” we establish the construct of consumers’ perceived morality of companies’ allocations of donation budgets that favor the own in-group as an important contingency factor in the relationship between varying geographic allocations and customer responses. Moreover, we draw on the results of our preliminary studies and interviews as well as literature on fair trade products and integrate into our model the notion of consumers' belief in a justice restoration potential of corporate donations. 
Second, this study is the first to explore the moral intuition that "charity should begin at home" or that "compatriots should take priority." The philosophical literature has intensively discussed this intuition, which was introduced into the philosophical dialogue by Henry Shue (1980, pp. 131-132). He describes this basic human intuition using the "pebble in the pond" example: like a pebble dropped into a pond, we see ourselves as the center of a system of concentric circles that become fainter as they spread. We feel that our duties are like the concentric ripples around the pebble, strongest at the center and rapidly diminishing toward the periphery. This patriotic bias has played a central role in the debate over universalistic moralities, such as cosmopolitan world views, in which equal concern or respect for individuals is a basic assumption. However, the ideal of an equal concern for all humanity contrasts sharply with the patriotic in-group favoritism of the pebble in the pond metaphor. Many timely examples vividly exemplify that patriotic beliefs still strongly shape the world we live in, such as restrictions on immigration. Obviously, governments do not hesitate to favor the interests of people bound together by a common nationality. Although the moral appeal of the cosmopolitan view is not hard to convey, the moral justification for donations based on patriotism is more difficult (Goodin 1988). The moral intuition of "compatriots take priority" is of crucial importance in our context, as prior contributions discussing this issue in the field of philosophy have typically assumed that people have an inherent preference for allocations favoring the own in-group. However, our investigation empirically indicates that this assumption is true for only a small group of respondents. The majority of the respondents favor fairly partitioning the donation between domestic and foreign recipients. Another significantly large group of respondents decides to allocate the entire donation to foreign recipients because they feel that these are more in need and they want to remedy global injustices. Further, the belief that one should give back 
to the international community plays a significant role in determining the amount that respondents allocate to foreign recipients. These findings are of high relevance for researchers who are interested in patriotic versus cosmopolitan world views and people's moral intuitions concerning these issues.

Third, we significantly broaden the knowledge on corporate philanthropy by revealing that current managerial practice in allocating donations is in conflict with customers' preferences. Past research on corporate philanthropy has convincingly documented that many companies focus their philanthropic activities on their direct surrounding. For instance, approximately $70 \%$ of the corporate philanthropy of corporations headquartered in MinneapolisSt. Paul concentrates on that specific area (Galaskiewicz 1997). Further, Marquis, Glynn, and Davis (2007) provide evidence for this headquarters-based pattern of social action by reviewing studies that consistently find that nearly $80 \%$ of corporate philanthropic spending is typically invested in the headquarters city (McElroy and Siegfried 1986; Kanter 1997; Guthrie 2003).

While this corporate giving pattern is in line with the moral intuition of "charity should begin at home," the results of our study reveal that this perspective might not be congruent with the views of the companies' customers, who are important primary stakeholders of the firm. The results of our four studies uniformly point to the fact that only a minority segment of customers prefers companies to focus their donation activity on domestic recipients. The majority of our nearly 6,000 respondents hold a world view that is characterized by a far more universal morality, considering the needs of all world citizens as equally relevant. Thus, for philanthropic actions to be in line with the preferences of customers, companies must view possible causes to support from a broader perspective.

Practical Implications 
Besides making these theoretical contributions, our results provide hands-on advice for CSR managers. Whereas for local companies the slogan "charity should begin at home" is supported by our empirical evidence, the good deeds should not end there and local companies can maximize customers' support by splitting their donation budgets between domestic and foreign recipients. In the case of MNCs, customers are indifferent as to whether the corporations choose to split donation budgets or only support causes abroad.

Importantly for CSR managers, customers’ perceived morality of favoring the own ingroup and their belief in a justice restoration potential of corporate donations play key roles in determining their reactions to such activities, and companies making corporate donations in the poorer regions of the world are advised to use this knowledge in their choice of causes and in their corporate communications.

First, in line with the majority opinion in all four studies, MNCs could frame split donation allocation decisions as an intention to "fairly allocate" their budgets. Further, they could explain that they intend to give back to the international community and that they choose causes that seem to be especially important owing to a high need. Second, they could explicitly point to the justice impact of their donation activity in their corporate communications. A possible approach would be to note that the recipients of the donations are subject to severe global injustices (e.g., that children in Indonesia do not have the same educational opportunities as children in Germany), and then explain how the donation activity of the company helps to combat this injustice.

Limitations 
The paper has some limitations that warrant mention. First, the studies reported in this paper were conducted in only one country (i.e., Germany), and the level of perceived morality of donation allocations favoring the in-group could very well vary between different countries and cultures owing to differences in collectivism, group cohesiveness, or moral intuition. Crosscultural studies could shed more light on these potential differences. In addition, the belief in a justice restoration potential of corporate donations could differ significantly across cultures owing to varying roles that private businesses play in the provision of public goods.

Avenues for Further Research

Obviously, companies in general and MNCs specifically are often perceived as resembling "agents of global justice" by consumers. This paper is the first to take this perspective to analyze customers' perceptions of philanthropic CSR activity. Further research could more deeply explore how consumers' expectations of the roles and duties of private businesses are changing and how companies should best respond to these new expectations. The fact that a considerable number of the respondents in the focus group interviews stated that companies should invest all that is left after costs are covered to further social goals may be symptomatic of a fundamental shift in how consumers view their corporate counterparts. Future research should attempt to more deeply explore this business-society interface using primary data on consumer perceptions. 


\section{References}

Bagozzi, R.P. \& Yi, Y. (1988). On the evaluation of structural equation models. Journal of the Academy of Marketing Science 16(1), 74-94.

Belk, R.W. (2006). Handbook of qualitative research methods in marketing. Edward Elgar Publishing Ltd., UK.

Bizumic, B., Duckitt, J., Popadic, D., Dru, V. \& Krauss, S. (2009). A cross-cultural investigation into a reconceptualization of ethnocentrism. European Journal of Social Psychology 39, 871-899.

Cleveland M., Laroche M. \& Papadopoulos N. (2009). Cosmopolitanism, consumer ethnocentrism, and materialism: an eight-country study of antecedents and outcomes. Journal of International Marketing 17(1), 116-46.

Creyer, E.H., \& Ross, W.T. (1996). The impact of corporate behavior on perceived product value. Marketing Letters 7(2), 173-185.

Cui, Y., Trent, E. S., Sullivan, P. M., \& Matiru, G. N. (2003). Cause related marketing: How generation Y responds. International Journal of Retail \& Distribution Management, 31(6/7), 310-320.

Dagger, R. (1985). Rights, boundaries, and the bonds of community: A qualified defense of moral parochialism. American Political Science Review 79(2), 436-447.

Du, S., Bhattacharya, C. B. \& Sen, S. (2007). Reaping relational rewards from corporate social responsibility: The role of competitive positioning. International Journal of Research in Marketing 24 (3), 224-41.

Eisenhardt, K. M. (1989). Building theories from case study research. Academy of Management Review 14(4), 532-550.

Fehr, E. \& Schmidt, K. M. (1999). A theory of fairness, competition, \& cooperation. Quarterly Journal of Economics, 817-868.

Fornell, C. \& Larcker, D. F. (1981). Evaluating structural equation models with unobservable variables \& measurement error. Journal of Marketing Research 18(1), 39-50.

Marquis, C., Glynn, M. A., \& Davis, Gerald F. (2007). Community isomorphism and corporate social action. Academy of Management Review 32 (3), 925-945.

McElroy, K. M., \& Siegfried, J. J. (1986). The community influence on corporate contributions. Public Finance Quarterly 14, 394-414.

Galaskiewicz, J. (1997). An urban grants economy revisited: Corporate charitable contributions in the Twin Cities, 1979-1981, 1987-1989. Administrative Science Quarterly 42, 445471.

Goodin, R. E. (1988). What is so special about our fellow countrymen? Ethics 98(4), 663-686.

Grau, S. L., \& Folse, J. A. G. (2007). Cause-related marketing (CRM): The influence of donation proximity and message framing cues on the less-involved consumer. Journal of Advertising, 36(4), 19-33.

Guthrie, D. (2003). Survey on corporate-community relations. New York: Social Sciences Research Council. 
Hou, J., Du, L., \& Li, J. (2008). Cause’s attributes influencing consumer's purchasing intention: Empirical evidence from China. Asia Pacific Journal of Marketing and Logistics, 20(4), 363-380.

Jöreskog, K. G., \& Sörbom, D. (1993). LISREL 8: Structural equation modeling with the SIMPLIS command language. Scientific Software International.

Kanter, R. (1997). World class: Thriving local in the global economy. New York: Touchstone Books.

Kim, J. Y., Natter, M. \& Spann, M. (2009). Pay-What-You-Want - A new participative pricing mechanism. Journal of Marketing, 73(1), 44-58.

Klein, J. \& Dawar, N. (2004). Corporate social responsibility \& consumers' attributions and brand evaluations in a product-harm crisis. International Journal of Research in Marketing 21(3), 203-217.

Lichtenstein, D. R., Drumwright, M. E. \& Braig, B. M. (2004). The effect of corporate social responsibility on customer donations to corporate-supported nonprofits. Journal of Marketing 68(4), 16-32.

Low, G. S., \& Lamb, C. W. Jr (2000). The measurement \& dimensionality of brand associations. Journal of Product \& Brand Management 9(6), 350-370

Luo, X., \& Bhattacharya, C. B. (2006). Corporate social responsibility, customer satisfaction, and market value. Journal of Marketing, 70(4), 1-18.

Muller, A., Whiteman, G. (2009). Exploring the geography of corporate philanthropic disaster response: A study of fortune global 500 companies. Journal of Business Ethics, 84, 589603.

Netemeyer, R. G., Bearden, W. O. \& Sharma, S. (2003). Scaling procedures. Issues and applications. Thousand Oaks, CA, 2003.

Podsakoff, P. M., MacKenzie, S. B., Lee, J. Y. \& Podsakoff, N. P. (2003). Common method biases in behavioral research: A critical review of the literature and recommended remedies. Journal of Applied Psychology 88, 879-903.

Robinson, S. R., Irmak, C. \& Jayachandran, S. (2012). Choice of cause in cause-related marketing. Journal of Marketing 76:4, 126-139.

Ross, J. K., Patterson, L. T., \& Stutts, M. A. (1992). Consumer perceptions of organizations that use cause-related marketing. Journal of the Academy of Marketing Science, 20(1), 93-97.

Ross, J. K., III, Stutts, M. A., \& Patterson, L. T. (1990-1991) Tactical considerations for the effective use of cause-related marketing. Journal of Applied Business Research, 7(2), 5865.

Russel, D.W. \& Russell, C. A. (2010). Here or there? Consumer reactions to corporate social responsibility initiatives: egocentric tendencies and their moderators. Marketing Letters, 21, 65-81.

Schons, L. M., Rese, M., Wiseke, J., Rasmussen, W., Weber, D. \& Strotmann, W. C. (2013). There is nothing permanent except change-analyzing individual price dynamics in "paywhat-you-want” situations. Marketing Letters 25(1), 25-36.

Shue, Henry (1980). Mediating duties. Ethics, 687-704. 
Takagishi, H., Kameshima, S., Schug, J., Koizumi, M. \& Yamagishi, T. (2010). Theory of Mind Enhances Preference for Fairness. Journal of Experimental Child Psychology 105 (1-2).

Vanhamme, J.; Lindgreen, A., Reast, J., \& van Popering, N. (2012). To do well by doing good: improving corporate image through cause-related marketing. Journal of Business Ethics, 109, 259-247.

Vlachos, P.A., Tsamakos, A., Vrechopoulos, A. P. \& Avramidis, P. K. (2009). Corporate social responsibility: attributions, loyalty, \& the mediating role of trust. Journal of the Academy of Marketing Science 37, 170-180.

White, K., MacDonnell, R. \& Ellard, J. H. (2012). Belief in a just world: Consumer intentions \& behaviors toward ethical products. Journal of Marketing 76, 103-118. 
Table 1 Study 4: Sample distributions by gender, age, income, and education Frequencies (\%)

\begin{tabular}{lc}
\hline Age & \\
$18-34$ years & 43.5 \\
$35-54$ years & 44.2 \\
More than 55 years & 12.3 \\
Sex & \\
Male & 28 \\
Female & 72 \\
Household income (after & \\
tax, monthly) & \\
Less than $1,000 €$ & 16.7 \\
1,001-2,500€ & 37.9 \\
2,501-3,500 $€$ & 25 \\
More than 3,501€ & 20.4 \\
Education & \\
CSE & 28.9 \\
Baccalaureate & 28.8 \\
Academic degree & \\
\hline Note: Based on $n=5,770$ participants. & \\
\hline & \\
\hline
\end{tabular}
Note: Based on $\mathrm{n}=5,770$ participants. 
Table 2 Study 4: Descriptive statistics and latent variable correlation coefficients ${ }^{\mathrm{r}}$

\begin{tabular}{|c|c|c|c|c|c|c|c|}
\hline & 1 & 2 & 3 & 4 & 5 & 6 & 7 \\
\hline $\begin{array}{l}\text { 1. Perceived morality of allocations favoring } \\
\text { the in-group }\end{array}$ & 1 & & & & & & \\
\hline 2. Justice restoration potential & $-.31^{* *}$ & 1 & & & & & \\
\hline 3. Involvement with product category & $-.11^{* *}$ & $.21^{* *}$ & 1 & & & & \\
\hline 4. Attitude toward philanthropy & $-.31^{* *}$ & $.34^{* *}$ & $.09^{* *}$ & 1 & & & \\
\hline 5. Attitude toward the out-group & $-.27^{* *}$ & $.34^{* *}$ & $.21^{* *}$ & $.30^{* *}$ & 1 & & \\
\hline 6. Purchase intentions & $-.18^{* *}$ & $.39^{* *}$ & $.18^{* *}$ & $.29^{* *}$ & $.27^{* *}$ & 1 & \\
\hline 7. Importance of cause & $-.24^{* *}$ & $.38^{* *}$ & $.17^{* *}$ & $.37^{* *}$ & $.30^{* *}$ & $.55^{* *}$ & 1 \\
\hline Mean & 3.51 & 4.51 & 4.57 & 5.06 & 4.57 & 3.95 & 4.61 \\
\hline Standard deviation & 1.56 & 1.39 & 1.85 & 1.49 & 1.21 & 1.59 & 1.51 \\
\hline Composite reliability & .81 & .82 & $\mathrm{a}$ & .92 & $\mathrm{a}$ & .92 & .92 \\
\hline Average variance extracted & .69 & .69 & $\mathrm{a}$ & .78 & $\mathrm{a}$ & .85 & .85 \\
\hline
\end{tabular}

${ }^{* *} p<.01$ (two-tailed)

r: Latent variable correlations are reported from the confirmatory factor analysis results, in which all multi-item and single-item latent variables are included. 
Figure 1 Conceptual framework and overview of studies

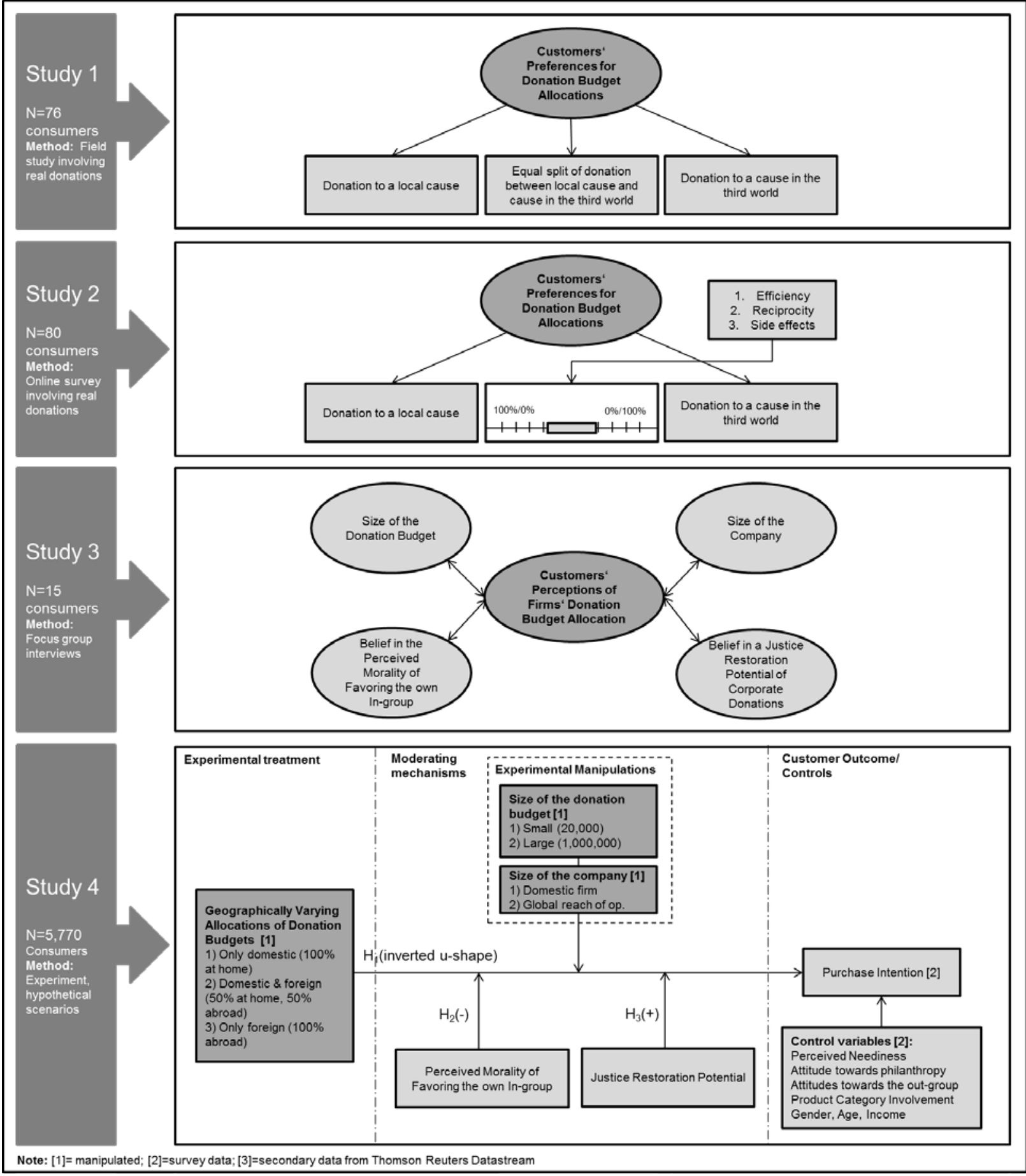


Figure 2 Study 2: Frequencies of donation allocation decisions

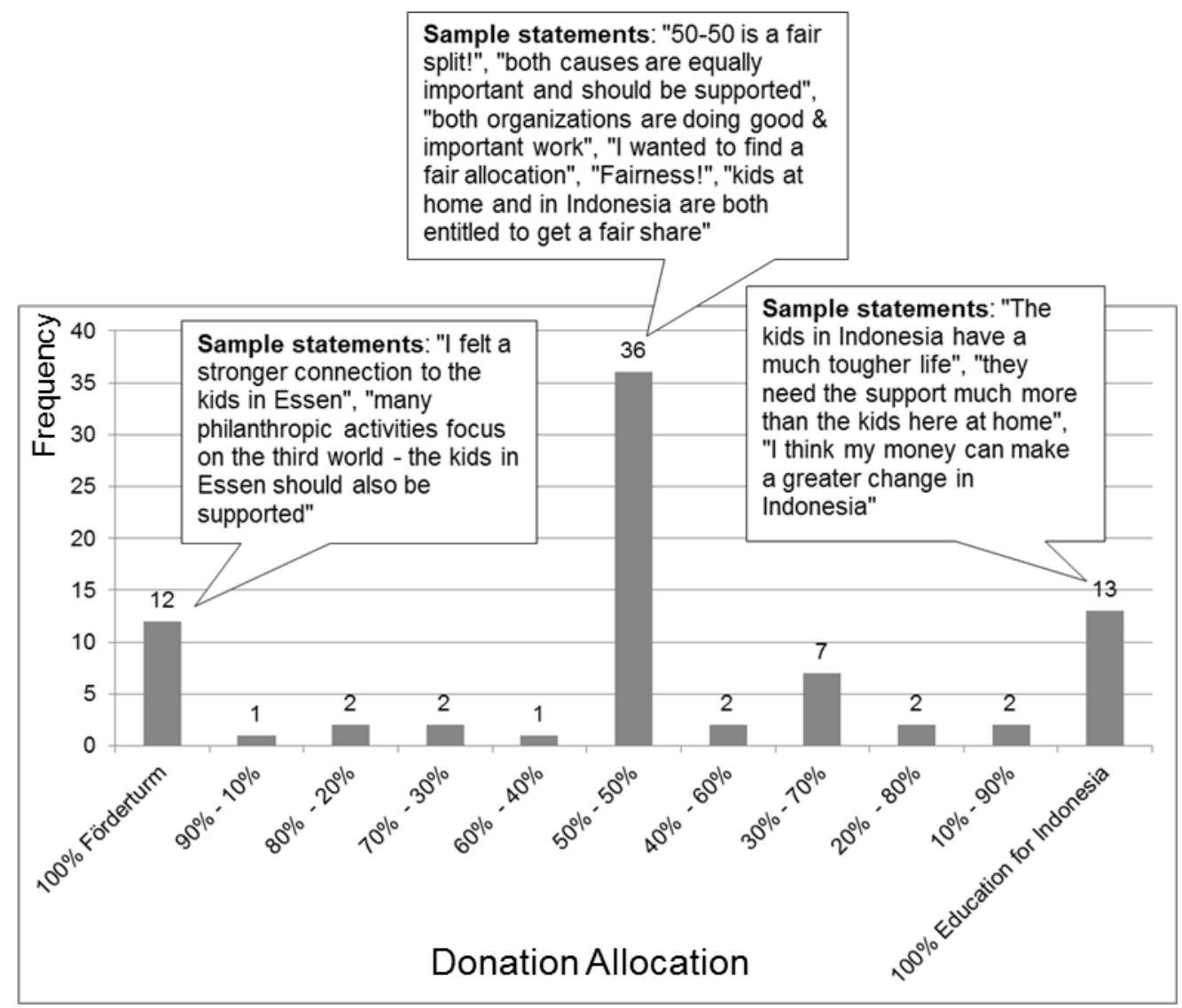


Figure 3 Study 4: Main effect of geographic allocation of donation budgets

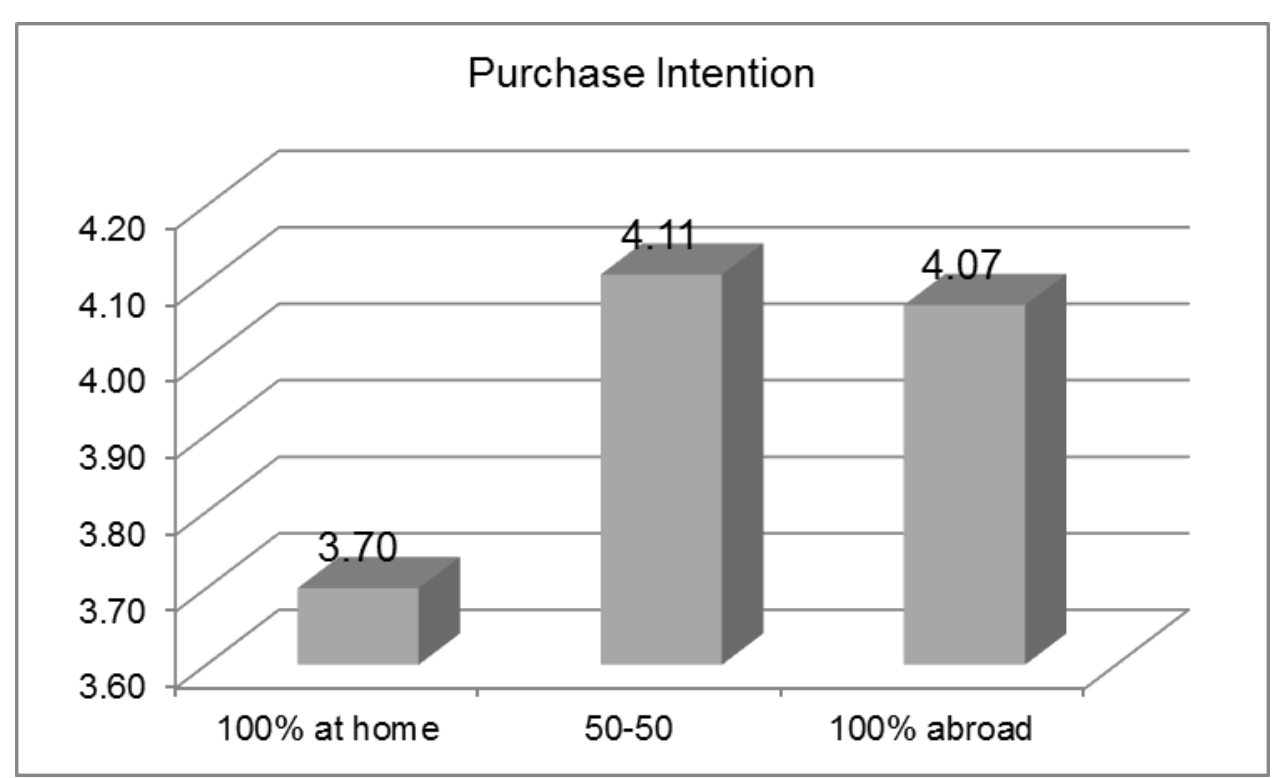


Figure 4 Study 4: Moderating effects

Perceived Morality of favoring the own ingroup

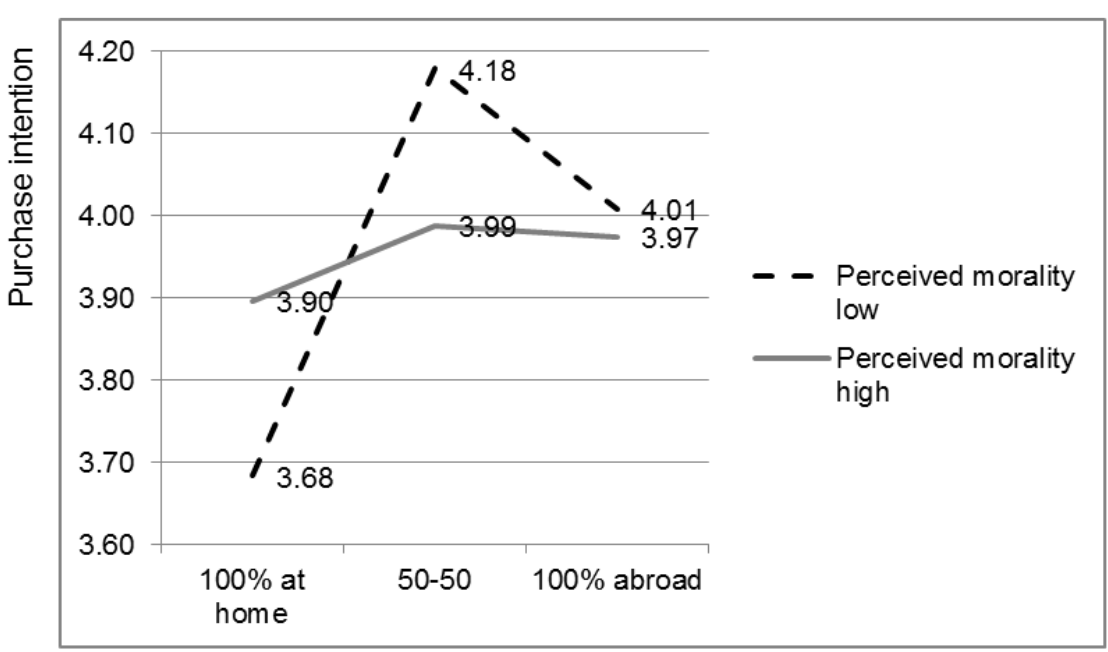

Justice Restoration Potential

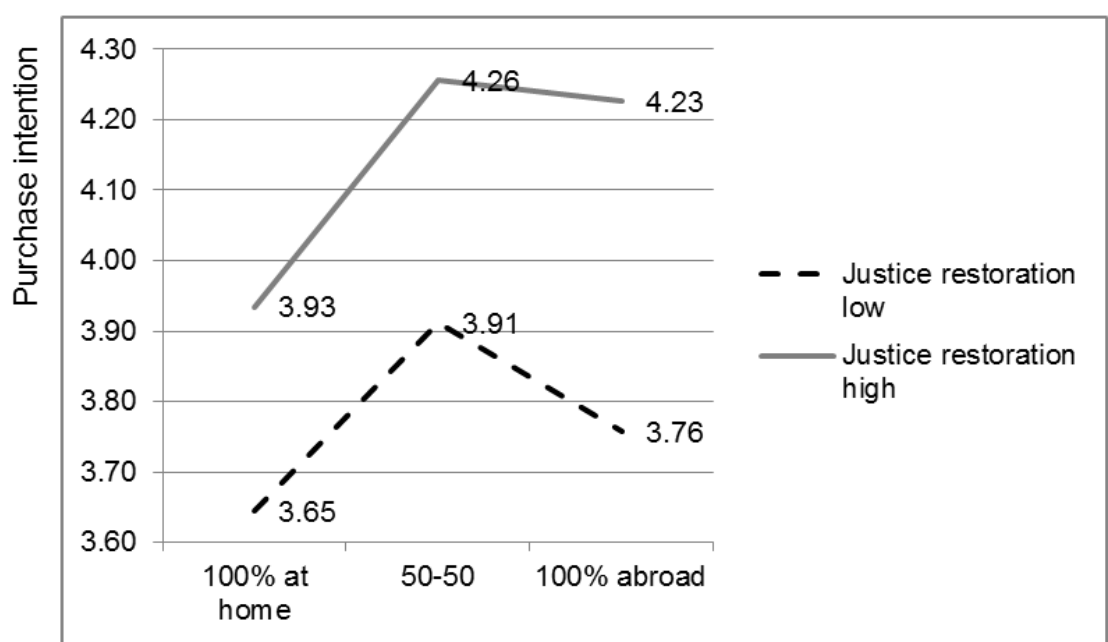


APPENDIX

Study 4: Measures and Scale Evaluation

Constructs and Measurement Items*
Perceived Morality of Donation Allocations Favoring the In-group
1. Under no circumstances it is morally acceptable for German companies to look more to the interests of
German people over foreigner customers and stakeholders.
2. German companies should not only do what's best for German people, even if it is at the expense of
German people.
3. German companies who are putting the interests of German people first, need to worry about how their
activities might affect people in other countries.*

\section{Justice Restoration Potential}

1. I can depend on certain companies to help make the world a fairer place for everyone.

2. I am confident that by purchasing from certain companies I can contribute toward restoring fair and just outcomes for people in foreign countries.

\section{Perceived Importance of Cause}

Supporting children in need...

1. Is of low importance to me... is of high importance to me.

2. Doesn’t mean anything to me ... means a lot to me.

\section{Attitudes toward Philanthropy}

1. I strongly believe that companies should donate some of their profits to children's charities.

2. Corporations have a responsibility to help children in need.

3. Businesses should stand up for the rights of children in need.

\section{Attitudes toward the Out-group}

1. I have a very positive attitude toward Indonesian people.

\section{Product Category Involvement}

1. Tea is very important to me.

Purchase Intentions ( $1=$ very unlikely; $7=$ very likely)

Composite

Reliability

.81

Self-developed scale based in qualitative study

Based on White, MacDonnell, and Ellard, 2012

Based on Lichtenstein, Drumwright, and Braig, 2004

92 Based on Lichtenstein, Drumwright, and Braig, 2004

Bizumic, Duckitt, Popadic, Dru, and Krauss, 2009

- $\quad$ Based on Cleveland, Laroche, and Papadopoulos, 2009

1. I would be likely to purchase this company's products.

2. I would likely make this company one of my first choices in this product category.

3. I would exert a great deal of effort to purchase this company's products.*

* Item deleted after CFA 